\title{
The Laguna Potrok Aike Scientific Drilling Project PASADO (ICDP Expedition 5022)
}

\author{
by Bernd Zolitschka, Flavio Anselmetti, Daniel Ariztegui, Hugo Corbella, \\ Pierre Francus, Christian Ohlendorf, Frank Schäbitz \\ and the PASADO Scientific Drilling Team
}

\section{Introduction}

In the Southern Hemisphere long, continuous, and high-resolution series of terrestrial paleoclimatic data are scarce, and they are only slowly emerging. Globally speaking, the most extreme oceanic character is encountered between $40^{\circ} \mathrm{S}$ and $60^{\circ} \mathrm{S}$ (Fig. 1). In this latitudinal belt ninety-eight percent of water is juxtaposed to only two percent of landPatagonia and a few sub-Antarctic islands. Therefore, records from Patagonia are a key to a better evaluation of inter-hemispheric linkages and differences in the climate system, especially as the Southern Ocean plays a key role for a proper understanding of the global climate system (Kaiser et al., 2007). Moreover, this region-close to the Andean volcanic chain-is one of the source regions for southern hemispheric dust. It is also subject to shifts in polar to mid-latitude pressure fields and precipitation regimes related to the Southern Hemispheric Westerlies and the Antarctic Oscillation. Patagonia thus potentially provides unique terrestrial records of variations in (1) climate, (2) hydrology, (3) erosion and deposition of atmospheric dust, and (4) volcanic activity. Additionally, links can be established to ice cores from Antarctica and to marine records from the South Atlantic where dust and tephra of Patagonian provenance have been deposited (Ackert, 2009; Narcisi et al., 2005; Sugden et al., 2009). For southernmost South America most lake sediments extend in time not beyond the Late-Glacial. However, Laguna Potrok Aike (Fig. 1) is older than the numerous Patagonian glacial lakes and offers the opportunity for volcanological studies.

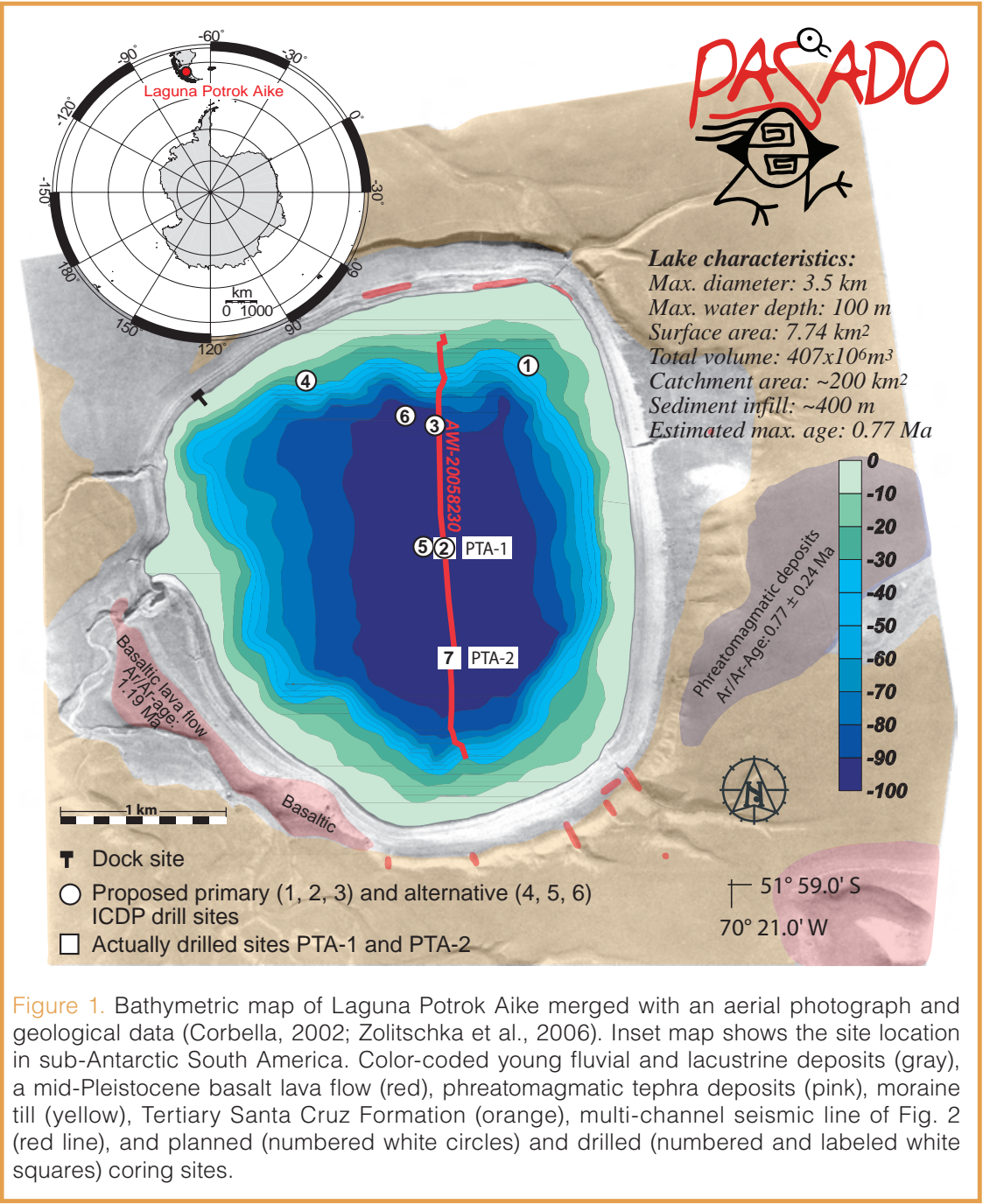

Laguna Potrok Aike developed in the Pliocene to late Quaternary Pali Aike Volcanic Field (Zolitschka et al., 2006). Located $100 \mathrm{~km}$ east of the Andean volcanic arc, this northwest-southeast oriented back arc volcanic belt is about $50 \mathrm{~km}$ wide and more than $150 \mathrm{~km}$ long. The oldest outcropping geological strata in the catchment area of Laguna Potrok Aike are Lower Miocene fine-grained fluvial sediments of the Tertiary Santa Cruz Formation (Blisniuk et al., 2005). During the Plio-Pleistocene (3.5-1.0 Ma) glaciers advanced northward from the Magellan Strait and covered the area now occupied by Laguna Potrok Aike. Thus, the surface of its catchment area today is dominated by fluvioglacial sediments and basal moraine tills of the most extensive glaciation (Coronato et al., 2004) with occasional exposures of basalts and volcanic spatter cones. The youngest glaciation that influenced the catchment area ended around 0.76 Ma (Singer et al., 2004) and left behind terminal moraines in Chile located $\sim 20 \mathrm{~km}$ south of Laguna Potrok Aike. Around $0.77 \mathrm{Ma}$, a phreatomagmatic explosion was triggered, creating a maar which developed into the lake of Laguna Potrok Aike (113 $\mathrm{m}$ a.s.1.). The lake is $100 \mathrm{~m}$ deep with a maximum diameter of $3.5 \mathrm{~km}$ (Fig. 1), and it has a surface area of $7.74 \mathrm{~km}^{2}$ (Zolitschka et 
al., 2006). The bathymetry is simple and pot-shaped, typical for a maar lake (Figs. 1, 2). The crater depression itself, only partly occupied by the lake, has a larger diameter of $5 \mathrm{~km}$. Because this basin has not been scoured by young glaciations, the crater lake of Laguna Potrok Aike is an ideal site for the recovery of long paleoenvironmental and paleoclimatic records. The lacustrine sedimentary infill potentially covers several glacial to interglacial cycles up to present times; it is underlain by coarse volcaniclastic rocks deposited immediately after the phreatomagmatic maar eruptions ceased.

The maar lake, with currently episodic tributaries, must be regarded as a subsaline terminal lake with a pH of 8.8 and a salinity of $2.2 \%$ due to the prevailing semiarid climate in the dry steppe environment of southernmost South America (Zolitschka et al., 2006). However, geomorphologic evidence suggests that overflow occurred northward in the past. Despite its great depth and large water volume, the lake has not developed a persistent seasonal stratification today. In response to the strong westerly winds, the lake is currently polymictic.

Rainfall within the catchment area of Laguna Potrok Aike is highly variable and is mainly rela-
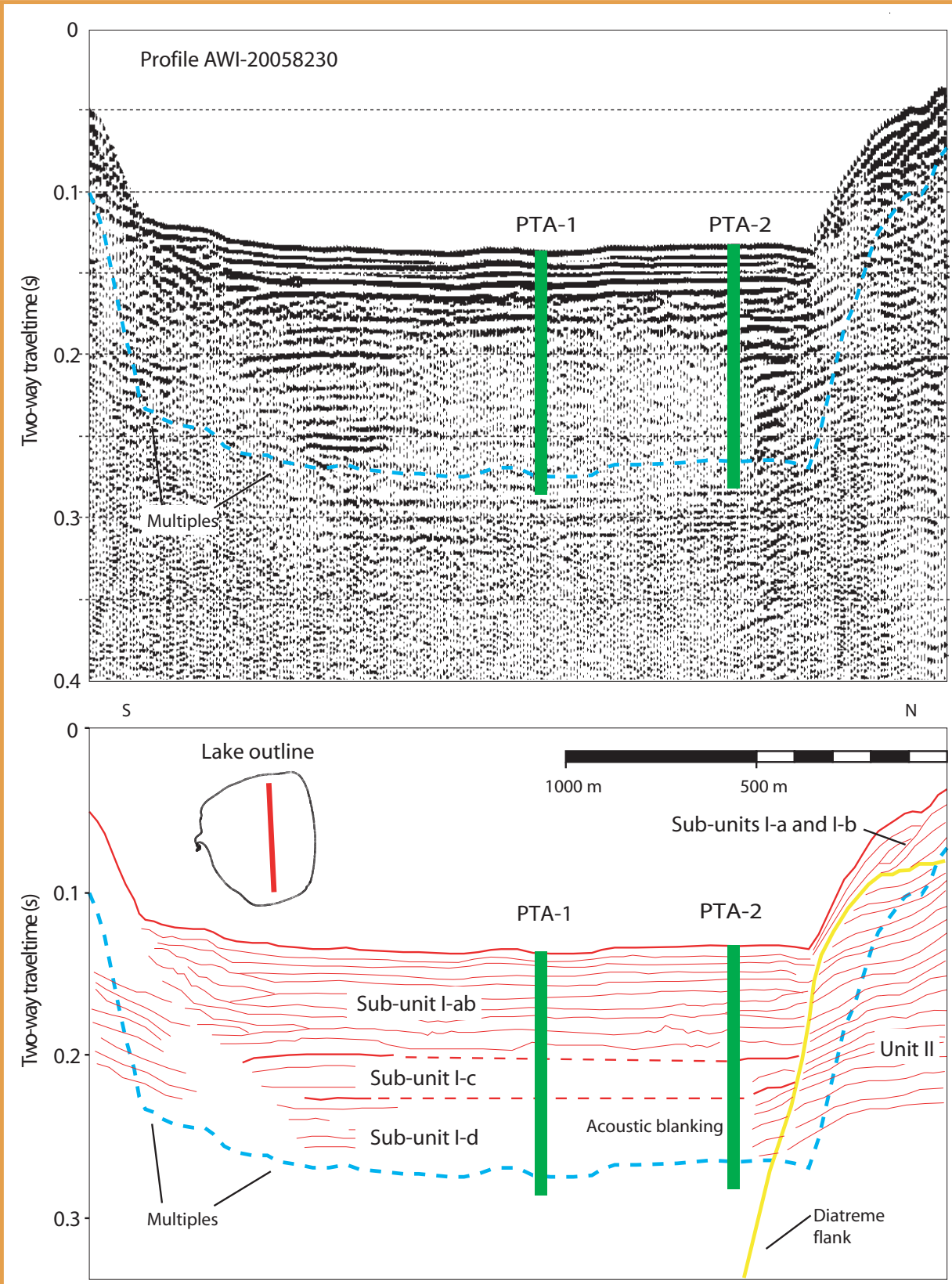

Figure 2. S-N multi-channel seismic reflection profile from Laguna Potrok Aike with uninterpreted seismic section (top) and interpreted line drawing (bottom). Drill sites PTA-1 and PTA-2 are marked. Inset (top left) shows outline of Laguna Potrok Aike with multi-channel seismic line (red) from Fig. 1.

ted to northward and southward shifts of the Southern Hemispheric Westerlies. A west wind belt over Southern Patagonia causes drier conditions (lee effect of the Andes), while a northward migration of the Westerlies allows rainbringing easterly winds to introduce precipitation from the Atlantic Ocean (Haberzettl et al., 2007b; Mayr et al., 2007). Therefore, a paleorecord from this site has a large potential to act as a cornerstone for paleodata-climate model intercomparison (Meyer and Wagner, 2008; Wagner et al., 2007). It makes the water budget extremely susceptible to the regional precipitation-evaporation balance. In addition, a multitude of surficial and subaquatic lake level terraces can be found. A continuous 16,000-year record with high temporal resolution and a low-resolution 53,000-year record exist for
Laguna Potrok Aike (Anselmetti et al., 2009; Haberzettl et al., 2007a, 2008; Mayr et al., 2007, 2009; Wille et al., 2007).

\section{Objectives, Project Planning and Drilling Operations}

The recent discovery of an exceptionally thick ( 400 m) sediment sequence for Laguna Potrok Aike (Anselmetti et al., 2009; Gebhardt et al., 2009) has sparked an international research effort directed towards an interlinked approach that addresses two key objectives: (1) the evolution of maar craters and (2) quantitative climatic and environmental reconstruction. 
Recovery of more than $400 \mathrm{~m}$ of sediments from a water depth of $100 \mathrm{~m}$ requires rotary drilling. The goal of the PASADO (Potrok Aike maar lake Sediment Archive Drilling prOject) deep drilling project was to recover triplicate cores from two sites and one core from a third site with inclined drilling (sites 1-6 in Fig. 1). The anticipated target depth ranged from $50 \mathrm{~m}$ to $600 \mathrm{~m}$ blf (below lake floor). Drill sites 2 and 5 (Fig. 1) had highest priority where seismic data indicated the potential for a penetration down to at least $400 \mathrm{~m}$ blf within the center of the basin, where hiatuses related to lake level fluctuations are less likely to exist (Fig. 2). Penetration was also planned into the volcaniclastic deposits below the $400 \mathrm{~m}$ or more of lake sediments. The second drilling target is located on the circum-lacustrine lake level terrace at $35 \mathrm{~m}$ water depth (sites 1 and 4 in Fig. 1). An erosional hiatus was detected there (Haberzettl et al., 2008). It is anticipated that this discontinuous record and the record from the lake center would jointly provide information about hydrological variations. The inclined drilling site is located near the northern end of the lake at $90 \mathrm{~m}$ water depth (sites 3 and 6 in Fig. 1) where a deviated hole was intended to be drilled through the crater wall and into basement rocks to investigate the transition zone formed during maar eruptions.

Drilling operations took place from September 2008 to November 2008. Prior to drilling, many logistical and technical challenges had to be overcome. The main obstacle was the lack of harbor facilities as well as the inaccessibility of the lake shore for a crane. Thus, the drilling platform had to be launched in a unique manner with a specially designed carriage called the "Launcher". This device made it possible to assemble the platform, including the drill rig and other heavy parts of equipment, on land and then lower the assembled barge downhill across the lake level terraces into a water depth sufficient to reach flotation. From the floating platform, drilling was carried out with the GLAD800 coring system operated by the Consortium for Drilling, Observation and Sampling of the Earth's Continental Crust (DOSECC) (Fig. 3). However, due to weather-related and technical downtime, only one of the primary sites (site 2, PTA-1) was drilled in quadruplicate and one additional site in the deep center of the lake (site 7, PTA-2) was drilled in triplicate. These sustained an average core recovery of 92.1\% (PTA-1) and $98.8 \%$ (PTA-2) (Table 1; Fig. 1). A total of $533 \mathrm{~m}$ of cores were obtained reaching a maximum depth of $101.5 \mathrm{~m}$ blf at the deepest hole (PTA-2C). Almost all coring was done with the Hydraulic Piston Corer (HPC), and one core run was drilled with the Extended Nose Corer (EXN). Rotary drilling was not applied because sediments at $100 \mathrm{~m}$ blf were still

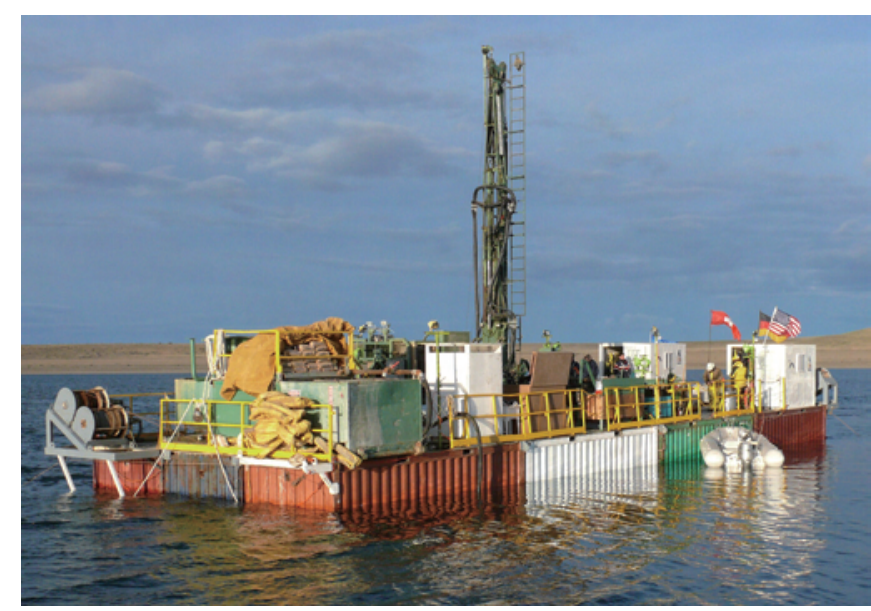

Figure 3. Platform R/V Kerry Kelts with the GLAD800 drilling system (center).

rather soft. The planned comprehensive downhole logging program combined with seismic experiments could not be conducted, due to the fact that all holes had to be abandoned in emergency because of unseasonably strong westerly winds.

In the field laboratory all cores were logged with the multi-sensor core logger (MSCL) provided by the ICDP. Magnetic susceptibility was obtained in 2-cm intervals for all cores. GRAPE (gamma ray attenuation porosity evaluation) density was not operational because we were not allowed to import the gamma ray source into Argentina. P-wave velocity measurements did not provide any signal, probably because the coupling between inner liner wall and sediment was imperfect. All core catcher samples were studied in the field laboratory for their physical and chemical properties including $\mathrm{pH}, \mathrm{Cl}^{-}, \mathrm{Ca}^{2+}$, electrical conductivity, water content, and dry density. Additionally, an initial lithologic description was carried out consisting of digital photography and macroscopic as well as microscopic description,(using smear slides for the latter). In addition, biotic activities related to early diagenetic processes were investigated as follows. This "deep biosphere" research tracks microbial activity through depth (Amend and Teske, 2005). On-site analyses included the detection of living organisms using ATP (adenosine triphosphate) measurements accompanied by sampling under the most sterile conditions possible. Immediate chemical fixation of the samples secured the best preservation of natural conditions for further laboratory studies. Sediment cores were then stored in a refrigerated container shipped to the GEOPOLAR Lake Core Repository at the University of Bremen where core splitting, scanning, and subsampling takes place.

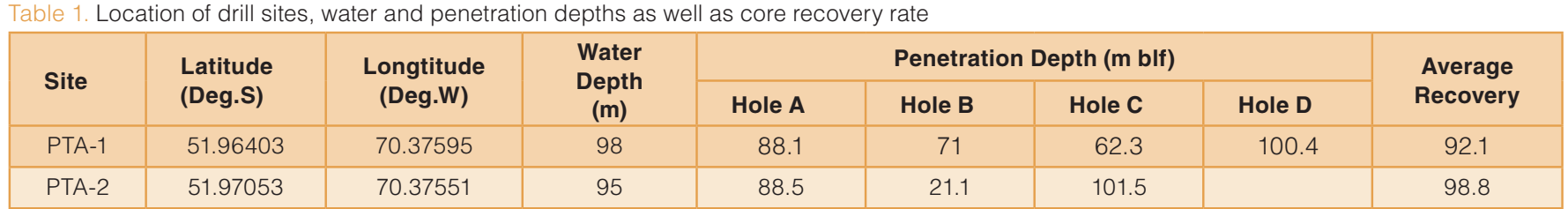



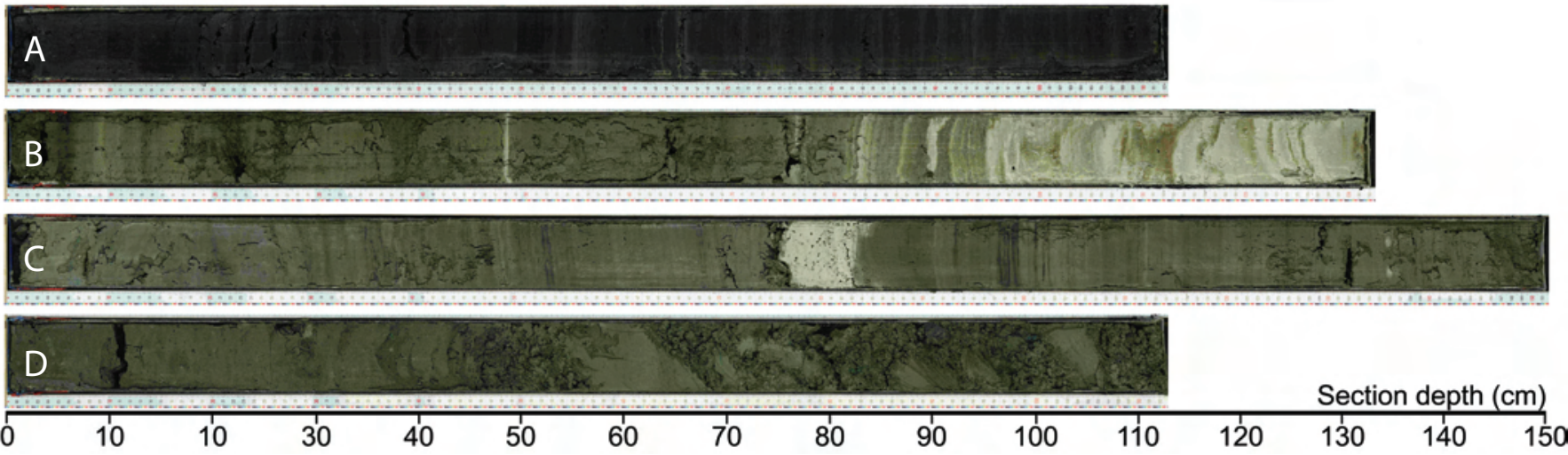

Figure 4. Selected split core sections from site PTA-2 (5022-2A). From top to bottom these represent [A] Holocene dark gray, laminated and carbonaceous silts starting from $6.39 \mathrm{~m}$ blf; [B] clastic and volcaniclastic, greenish-gray laminated and carbonaceous silts from $13.52 \mathrm{~m}$ blf; [C] clastic and volcaniclastic, greenish-gray laminated silts from $28.54 \mathrm{~m}$ blf; [D] clastic, greenish-gray sand and gravel from $82.52 \mathrm{~m}$ blf.

\section{Preliminary Results}

During the ICDP field work we recovered the longest environmental and climatic record (so far) for South America south of the tropics. However, lacustrine deposits were not penetrated completely, and volcaniclastic sediments were not reached. The total catch of cores was only $29 \%$ of what was proposed; thus, one of the two objectives of PASADOthe study of the basal volcaniclastic sediments-was not addressed.

All cored holes were correlated by applying MSCL (magnetic susceptibility core logger) data. The longest $(101.5 \mathrm{~m})$ lacustrine record consists mainly of lacustrine mud. Despite this dominance, grain sizes vary considerably from layers of almost pure clay and sandy sections (especially

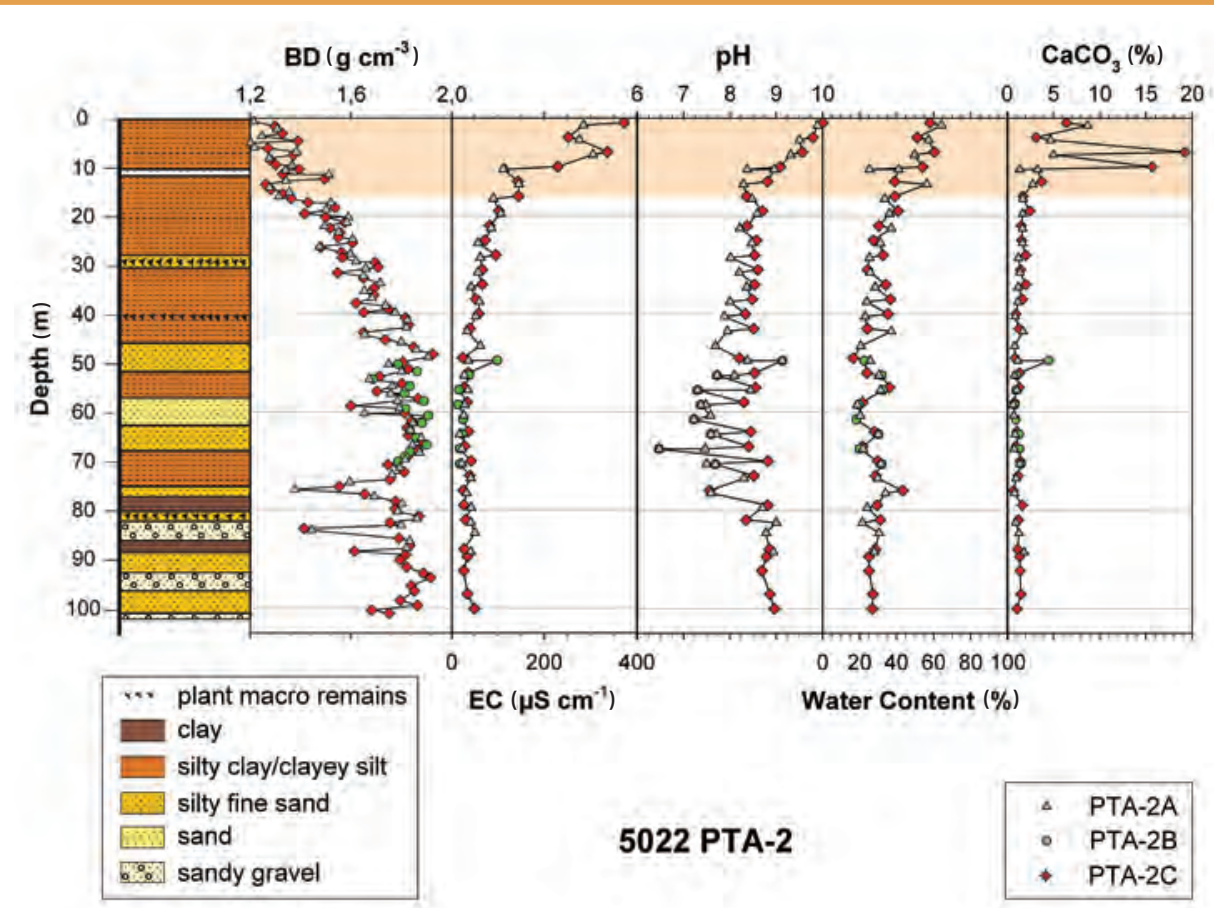

Figure 5. Lithostratigraphy and records of bulk density (BD), electrical conductivity (EC), $\mathrm{pH}$, water content, and carbonate content $\left(\mathrm{CaCO}_{3}\right)$ based on core catcher samples from site PTA-2 (combined holes $\mathrm{A}, \mathrm{B}$, and $\mathrm{C}$ ) as obtained in the field laboratory. The Holocene section of the record is shaded in an orange hue (top) below $50 \mathrm{~m}$ blf) to gravel beds (Fig. 4). Some of the latter are related to volcanic ash layers consisting of sands with coarser scoria components. Surprisingly enough, rounded gravels were also recovered from the center of Laguna Potrok Aike. This can only be explained by either drastic lake level lowering until fluvial activity reached the coring site or seasonal lake freezing during the last glacial with snowmelt-related slush flows deposited onto the ice cover and coarse particles relocated as drop stones. We favor the latter interpretation, because lake level lowering should cause precipitation of evaporates like they presently occur at Laguna Maar Bismarck, a modern analogue for such conditions in the Pali Aike Volcanic Field.

There is a clear Holocene signal in the core catcher data (Fig. 5). However, the presence of older interglacial (Eemian; Oxygen Isotope Stage $=$ OIS 5.5) is missing within the recovered sections. This finding is consistent with linear extrapolation of the age model developed for piston cores of the last $16 \mathrm{ka}$ (Haberzettl et al., 2007b), and it suggests an estimated age of $\sim 85 \mathrm{ka}$ for the lowermost sediment recovered. Preliminary microfossil analyses of core catcher samples show a clear difference between Holocene and glacial conditions in the upper part of the profile, and reveal increases in diatom frequency and pollen of shrub taxa for the lowermost part of the profile. Based on these data, the obtained sediment record may extend back to OIS 5.1.

\section{Summary}

The 770-ka-old maar lake of Laguna Potrok Aike was the target 
of the international deep drilling project PASADO, carried out in the framework of the ICDP from September to November 2008. Although the project could not recover the entire lacustrine sediment infill and volcaniclastics due to unusually windy conditions and technical problems, PASADO drilled seven holes at two sites in the central deep lake basin to a maximum depth of $101.5 \mathrm{~m}$ blf. A total of $533 \mathrm{~m}$ of sediment cores was gathered with a mean recovery rate of 95.5\%. Currently, sediments of this longest Patagonian lake record to date are subsampled and analyzed. First detailed scientific results are expected for the year 2010.

\section{Acknowledgements}

We are grateful to Beau Marshall and the DOSECC drilling crew as well as to Capitan Jorge Daniel Moreteau and his son Javier for their excellent technical skills. Without them the PASADO field work would not have been possible. We also thank the members of Instituto Nacional de Tecnología Agropecuaria (INTA) Santa Cruz, in particular Guillermo Clifton and Gabriel Oliva, for providing logistical support and the ground for the field camp at their experimental field station Potrok Aike. Many thanks go as well to Cristobal Zimmermann of the German Embassy in Buenos Aires. Without his steady support many customs affairs would have been unsolvable for us.

Preparatory studies were supported by the German Federal Ministry of Education and Research (BMBF) in the framework of the German Climate Research Program (DEKLIM and SALSA) and through the projects POTROK and ASADO within the Priority Program "ICDP" of the German Science Foundation (DFG).

This research is supported and partially funded by the ICDP. Co-funding for drilling as well as for currently ongoing scientific investigations is provided by the German Science Foundation (DFG), the Swiss National Science Foundation (SNF), the Natural Sciences and Engineering Research Council of Canada (NSERC), the Swedish Vetenskapsradet (VR), and the University of Bremen.

\section{The PASADO (ICDP Expedition 5022) Scientific Drilling Party}

B. Zolitschka (Co-Chief Scientist), C. Ohlendorf (Co-Chief Scientist), F. Anselmetti, D. Ariztegui, H. Corbella, S. Delpit, R. Farah, V. Förster, D. Fortin, P. Francus, C. Gebhardt, T. Grelle, T. Haberzettl, A. Hahn, S. Kastner, P. Kliem, O. Langkamp, A. Lisé-Pronovost, C. Mayr, F. Müller, D. Penshorn, C. Recasens, P.-S. Ross, F. Schäbitz, G. St-Onge, A. Stopp, D. Veres, and A. Vuillemin.

\section{References}

Ackert, R.P., Jr., 2009. Patagonian dust machine. Nature Geosci., 2:244-245, doi:10.1038/ngeo485.
Amend J.P., and Teske A., 2005. Expanding frontiers in deep subsurface microbiology. Palaeogeogr., Palaeoclimatol., Palaeoecol., 219:131-155, doi: 10.1016/j.palaeo.2004.10.018

Anselmetti, F.S., Ariztegui, D., De Batist, M., Gebhardt, A.C., Haberzettl, T., Niessen, F., Ohlendorf, C., and Zolitschka, B., 2009. Environmental history of southern Patagonia unravelled by the seismic stratigraphy of Laguna Potrok Aike. Sedimentology, 56:873-892, doi:10.1111/j.1365-3091. 2008.01002.x.

Blisniuk, P., Stern, L., Chamberlain, C., UIdleman, B., and Zeitler, P., 2005. Climatic and ecological changes during Miocene surface uplift in the Southern Patagonian Andes. Earth Planet. Sci. Lett., 230:125-142, doi:10.1016/j.epsl.2004.11.015.

Corbella, H., 2002. El campo volcano-tectónico de Pali Aike. In Haller, M. (Ed.), Geología y Recursos Naturales de Santa Cruz, Buenos Aires (Asociación Geológica Argentina), 285-302.

Coronato, A., Martinez, O., and Rabassa, J., 2004. Glaciations in Argentine Patagonia, southern South America. In Ehlers, J., and Gibbard, P.L. (Eds.), Quaternary Glaciations - Extent and Chronology, Part III: South America, Asia, Africa, Australasia, Antarctica. Developments in Quaternary Science, Vol. 2c, Amsterdam, The Netherlands (Elsevier), 49-67.

Gebhardt, A.C., De Batist, M., Niessen, F., Anselmetti, F.S., Ariztegui, D., Kopsch, C., Ohlendorf, C., and Zolitschka, B., 2009. Origin and evolution of the Laguna Potrok Aike maar, Southern Patagonia. Basin Research, in review.

Haberzettl, T., Corbella, H., Fey, M., Janssen, S., Lücke, A., Mayr, C., Ohlendorf, C., Schäbitz, F., Schleser, G.-H., Wessel, E., Wille, M., Wulf, S., and Zolitschka, B., 2007a. A continuous 16,000 year sediment record from Laguna Potrok Aike, southern Patagonia (Argentina): sedimentology, chronology, geochemistry. The Holocene, 17:297-310, doi:10.1177/0959683607076437.

Haberzettl, T., Kück, B., Wulf, S., Anselmetti, F., Ariztegui, D., Corbella, H., Fey, M., Janssen, S., Lücke, A., Mayr, C., Ohlendorf, C., Schäbitz, F., Schleser, G., Wille, M., and Zolitschka, B., 2008. Hydrological variability and explosive volcanic activity in southeastern Patagonia during Oxygen Isotope Stage 3 and the Holocene inferred from lake sediments of Laguna Potrok Aike, Argentina. Palaeogeogr., Palaeoclim., Palaeoecol., 259:213-229, doi:10.1016/j. palaeo.2007.10.008.

Haberzettl, T., Mayr, C., Wille, M., and Zolitschka, B., 2007b. Linkages between southern hemisphere westerlies and hydrological changes in semi-arid Patagonia during the last 16,000 years. PAGES News, 15(2):22-23.

Kaiser, J., Lamy, F., Arz, H., and Hebbeln, D., 2007. Variability of seasurface temperatures off Chile and the dynamics of the Patagonian Ice Sheet during the last glacial period based on ODP Site 1233. Quaternary Intl., 161:77-89, doi:10.1016/j. quaint.2006.10.024.

Mayr, C., Lücke, A., Maidana, N.I., Wille, M., Haberzettl, T., Corbella, H., Ohlendorf, C., , Schäbitz, F., Fey, M., Janssen, S., and Zolitschka, B., 2009. Isotopic and geochemical fingerprints on lacustrine organic matter from Laguna Potrok Aike (southern Patagonia, Argentina) reflect environmental changes during the last 16,000 years. J. Paleolimnol., 42:81102, doi: 10.1007/s10933-008-9249-8.

Mayr, C., Wille, M., Haberzettl, T., Fey, M., Janssen, S., Lücke, A., 
Ohlendorf, C., Oliva, G., Schäbitz, F., Schleser, G.H., and Zolitschka, B., 2007. Holocene variability of the Southern Hemisphere westerlies in Argentinean Patagonia (52 ${ }^{\circ}$ S). Quat. Sci. Rev., 26:579-584, doi:10.1016/j.quascirev. 2006.11.013.

Meyer, I., and Wagner, S., 2008. The Little Ice Age in southern Patagonia: comparison between paleoecological reconstructions and downscaled model output of a GCM simulation. PAGES News, 16:12-13.

Narcisi, B., Petit, J.R., Delmonte, B., Basile-Doelsch, I., and Maggi, V., 2005. Characteristics and sources of tephra layers in the EPICA-Dome C ice record (East Antarctica): implications for past atmospheric circulation and ice core stratigraphic correlations. Earth Planet. Sci. Lett., 239:253-265, doi:10.1016/j.epsl.2005.09.005.

Singer, B.S., Ackert, R.P., and Guillou, H., 2004. ${ }^{40} \mathrm{Ar} / 39 \mathrm{Ar}$ and K-Ar chronology of Pleistocene glaciations in Patagonia. Geol. Soc. Am. Bull., 116:434-450, doi:10.1130/B25177.1.

Sugden, D.E., McCulloch, R.D., Bory, A.J.-M., and Hein, A.S., 2009. Influence of Patagonian glaciers on Antarctic dust deposition during the last glacial period. Nature Geosci., 2:281-285, doi:10.1038/ngeo474.

Wagner, S., Widmann, M., Jones, J., Haberzettl, T., Lücke, A., Mayr, C., Ohlendorf, C., Schäbitz, F., and Zolitschka, B., 2007. Transient simulations, empirical reconstructions and forcing mechanisms for the Mid-Holocene hydrological climate in Southern Patagonia. Clim. Dyn., 29:333-355, doi:10.1007/ s00382-007-0229-x.

Wille, M., Maidana, N.I., Schäbitz, F., Fey, M., Haberzettl, T., Janssen, S., Lücke, A., Mayr, C., Ohlendorf, C., Schleser, G.H., and Zolitschka, B., 2007. Vegetation and climate dynamics in southern South America: the microfossil record of Laguna Potrok Aike, Santa Cruz, Argentina. Rev. Palaeobot. Palynol., 146:234-246, doi:10.1016/j.revpalbo.2007.05.001.

Zolitschka, B., Schäbitz, F., Lücke, A., Clifton, G., Corbella, H., Ercolano, B., Haberzettl, T., Maidana, N., Mayr, C., Ohlendorf, C., Oliva, G., Paez, M.M., Schleser, G.H., Soto, J., Tiberi, P., and Wille, M., 2006. Crater lakes of the Pali Aike Volcanic Field as key sites of paleoclimatic and paleoecological reconstructions in southern Patagonia, Argentina.J. South Am. Earth Sci.,21:294-309, doi:10.1016/j. jsames.2006.04.001.

\section{Authors}

Bernd Zolitschka, Geomorphology and Polar Research (GEOPOLAR), Institute of Geography, University of Bremen, Celsiusstraße FVG-M, D-28359 Bremen, Germany, e-mail: zoli@uni-bremen.de.

Flavio Anselmetti, Swiss Federal Institute of Aquatic Science and Technology (Eawag), Department of Surface Waters, Überlandstrasse 133, CH-8600 Dübendorf, Switzerland.

Daniel Ariztegui, Section of Earth \& Environmental Sciences, University of Geneva, Rue de Maraîchers 13, CH-1205 Geneva, Switzerland.

Hugo Corbella, Argentine Museum of Natural History, Av. Angel Gallardo 470, Buenos Aires, Argentina.
Pierre Francus, Institut National de la Recherche Scientifique, Centre Eau, Terre et Environnement, 490 rue de la couronne, Québec, QC G1K 9A9, Canada.

Christian Ohlendorf, Geomorphology and Polar Research (GEOPOLAR), Institute of Geography, University of Bremen, Celsiusstraße FVG-M, D-28359 Bremen, Germany.

Frank Schäbitz, Seminar for Geography and Education, University of Cologne, Gronewaldstr. 2, D-50931 Cologne, Germany.

and the PASADO (ICDP Expedition 5022) Science Team.

\section{Related Web Links}

http://www.pasado.uni-bremen.de http://www.icdp-online.org/contenido/icdp/front_content. php?idart $=2185$

\section{Figure and Photo Credits}

Fig. 1: Corbella, 2002 and Zolitschka et al., 2006 (both with modifications); inserted map source: Online Map Creation (http://www.aquarius.geomar.de)

Fig. 2: Data by Gebhardt et al. 2009

Fig. 3: Photo by B. Zolitschka, University of Bremen Fig. 4: Photo by C. Ohlendorf, University of Bremen 